\title{
Translators' Selections from Heine as Lyric Cycles
}

\author{
Andrei V.Achkasov* \\ St. Petersburg State University \\ 7/9 Universitetskaya nab., St. Petersburg, \\ 199034, Russia
}

Received 24.02.2018, received in revised form 11.04.2018, accepted 24.04.2018

Traditionally, poetic anthologies have not been seen as single, compositional wholes. However, this article shall employ translations of Heinrich Heine to demonstrate that such collections are not mere random occurrences. Rather, they may be characterised by a certain deliberation and a sense of their own compositional completeness. The analysis here posed allows us to raise the question of the relationship between translations of poetic cycles/anthologies and their arrangement as cycles in the original. We shall also consider the original creative intentions of translators who take pains to select the verses they will work upon and to assemble them for publication. We shall argue that translation anthologies must balance two motivations: the effort to represent the lyrical decisions of the original author and the effort to create a new lyric cycle on the part of the translator/co-author.

Keywords: lyric cycles, Heine, translation, poetic anthology, translators' selections, recyclization.

DOI: 10.17516/1997-1370-0262.

Research area: linguistics, culturology.

\section{Introduction}

Issuing anthologies of poetry translations from differing selections of poets and of differing length was a typical practise of $19^{\text {th }}$ century print culture and one maintained over the whole of the $20^{\text {th }}$ century. Traditionally, such anthologies have not been viewed as single, compositional wholes. Of course the translations collected in such anthologies could have been done at different times and taken from different collections of the poet's works; yet we may propose that in each individual case the selection of verse for translation was not accidental and was determined by the translator's poetic preferences. Their collection into modest anthologies can serve to characterise a particular autonomy, completeness and sense of composition. This has special importance if the anthology gathers together translations that the poet published as his or her own cycles of verse. In these cases the new collection is 'selected' out of the context of the original and sets it in a new context. One might provisionally call such compositions 'recycling' as a particular example of the original poet's reception. Such a practise is typical of translations of Hienrich Heine's poetry which was actively published in $19^{\text {th }}$ century journals.

(c) Siberian Federal University. All rights reserved

* Corresponding author E-mail address: a_v_achkasov@mail.ru 


\section{Translator's intention vs. original cycles}

Translations of Hiene's lyric were mostly published as groups/collections gathered together from different cycles of the poet's work. Their size ranged from one to two, to scores of miniatures. The question as to whether one should look at these various anthologies as cycles or forms of cycles must be individually resolved in each particular case. This brings up a number of problems that are not traditional to the analysis of poetic cycles.

First amongst them is the problem of the relations between at once the translated cylces/ anthologies and the original cycles as Heine conceived them and the particular authorial intentions of his translators, many of whom were themselves renowned Russian poets with their own original cycles of verse. When the question is posed this way, the 'originality' of the translated cycles/anthologies becomes diminished a priori. They are not themselves cycles, but rather 'recycles'; that is, works oriented at one level or another toward the original. They are shaped, in the end, by the authorial intentions of the translator.

This two-sidedness of 'recycling' is directly related to the problem of selecting poems for translation. "A rupture from the cycle, from its immediate environment or general literary background, or a violation of its ties with such a background, is an inevitable fact of translation. The very choice of a particular work for translation is already a patent liberty taken with the material. A one-sided collection of verse may give a historically inaccurate impression of the system of a poet such as Heine." (Fedorov, 1920: 253). A selection of verse which represents itself as 'taking liberties with the material' goes along with that factor reflecting the creative intentions of the translator and ontologically determining certain particularities of its anthology/cycle (its thematic or genre orientation). In certain rare cases selection of works is prompted by 'external' factors. Some translators worked on commission (A.N.Maikov put together his first collection from translations done, on the whole, for articles written by A. von Vidert). In the 1860s several translators attempted to render only miniatures which had not yet been translated. Others, on the other hand, tried to set the more well-known miniatures into their own versions. More often than not, the nature of the compositions selected is determined by the translator's preferences which, in turn, determines the possibility of incorporating translations into a cyclic form.

Publication practise of Heine's translations required that they be collected in groups or anthologies; though it was far from rare, especially in the 1840 s, for poetic works to also be published individually. The incorporation of translations into groups was aided by the fact that they were published in small 'portions' as they accumulated. As has been stated above, the question of the originality of anthologies/sections/ books of Heine translations demanded, in each case, an individual decision. Furthermore, for small anthologies (often for journal publications) there were certain obvious tendencies governing how translations were put together.

\section{'Triptychs' from Heine}

For journals in the middle of the $19^{\text {th }}$ century, the most typical collection was one from between two poems to up to seven to ten. A model for such collections could have been the small set-piece cycles such as the 'Book of Song' ('Buch der Lieder') and the 'New Poems' ('Neue Gedichte'). Translators did not so much follow Heine's own principles of setting poems into cycles as they took the original cycles' aim of setting collections of verses into small groupings. However, miniatures collected under a separate title and numeration (such as the 'lyric novels', 
listed in Pisarev's discussion above) were not the only ones serving as models for the construction of small collections. In this sense, models of interaction and verse compilation were more greatly influenced by the larger and more often translated cycles of the 1840 s to 1860 s, namely the 'Lyrical intermezzo' ('Lyrisches Intermezzo'), 'Returning Home' ('Die Heimkehr'), 'New spring' ('Neuer Frühling'), and others. They often gathered miniatures together into thematic groups, while the borders between groupings bled into one another. The same verses could become members in several groupings at once on the basis of different parameters - theme, metre or genre. Moreover, some poems absent from adjacent cycles might still be grouped together if they exhibited some sort of secondary, overlapping internal 'line'. Heine's cycles are progressive, 'kaleidoscopic' mosaics. An emerging narrative movement can be broken by a sudden shift of genre, metrical or rhythmic plane. Motifs contrary to emotional or plot-driven concerns can jerk forward in abrupt, diagonal transitions.

For example, the poems 'Mondscheintrunke Lindenbluten...' and 'Durch den Wald; im Mondenscheine...' of the 'New Spring' cycle (\#31 and 32) are connected by a moonlight motif. This obvious connection could have prompted their reception as a diptych. There are many such examples. A.N. Maikov renders numbers 26 and 27 as a 'pair' of poems of the same cycle as they are connected by a nocturnal motif. The moonlight motif appears several times in the cycle and establishes a recurrent effect throughout the poems. However, the poem 'Mondschientrunke Lindenbluten...' is chiasmatically related with the first verse of this cycle and this juncture is no less important for the structure of the cycle as a whole. Yu.N. Tynyanov notes: 'The poem which begins the collection ['New Spring'], 'Unterm weißen Baume sitzend'. (Here the poet, beneath a whiteblooming tree, listens to the blow of the wind, attends to mute, passing clouds. White clumps fall from the boughs and, dismayed, he thinks that the tree is casting snow down upon him. But with a kind of elated fear he notes that this not snow, but spring flowers. Winter turns to May, to blossoms, and his heart loves again.) By the end of the collection, the $31^{\text {st }}$ poem is built upon a reverse of the conceit: sitting beneath a blooming lime (linden) tree, the poet dreams of heaps of winter snow.' (Tynyanov 1977: 364). These poems are also linked to the motif of whitening, (white trees and white snow). The nearly symbolic white motif appears in other poems within the cycle, particularly in the aforementioned 'Durch den Wald; im Mondenscheine...' (weiße Rößlein), and others. These sorts of cross-references are innumerable in Heine's work. Yu. Tynyanov, referencing German-language Heine criticism practically unknown in Russian cyclic studies, writes: 'When Heine published his poetry in collections: 'Leiden', 'Lyrisches Intermezzo', 'Heimkehr', 'Neuer Frühling', for example, he carefully attended to the ordering of individual poems, altering it several times. Each collection was characterised with an intentional, as Elster terms it, "plasticity" in its positioning. Elster has established the grouping of poems and internal principles of their placement with great precision. Though differing from one other in each collection these principles may, however, coalesce into basic principles for Heine's division of prose into chapters...' (Tynyanov, 1977: 378). Later on he cites the opinion of M. Ebert: 'Thanks to this division, he [Heine] accomplishes a tangible play of external contrasts. Pointe and Witz could be more textured as a result of short divisions and sudden breaks, and could without a transition amount to a new approach to the thinking behind them' (Tynyanov, 1977: 378).

Although $19^{\text {th }}$ century translators did not reflexively consider these particularities of Heine's cycles, they managed to find their own 
reflection in their anthologies. If the connections between miniatures in Heine's cycles are set against the context of their generally fragmented nature (the skips and jumps across theme, metre, rhythm and genre), then the smaller anthologies of translations are where the obvious (for the most part thematic) connecting elements are 'regenerated'. This unifying principle can be found in, for example, F. Miller's diptichs. They put together the verses 'Utrom dolgo ya zhdu...' ('Morgens steh' ich auf und frage...', 'die Lieder', \#1) and 'Kak sny polunochnye zdanya' ('Wie dunkle Träume stehen...', 'Die Heimkehr', \#71) (Miller, 1844: 3). In the first miniature, the lyric hero waits the whole day for a 'dear one', in the second she waits for him and he goes to her by night. In another diptych, likewise made up of poems from different cycles ('Znat' plyasku groza zatevayet...', 'Nedvizhno v dalekom efire ...' 'Der Sturm spielt auf zum Tanze...', 'Es stehen unbeweglich...') (Miller 1848: 14) the principle of assembling the miniatures is a somewhat different, though still with an unmediated exchange of motifs. Miller uses the diptych form several times. He published the translation of Heine's dyptych separately as 'Sonety k materi' ('Sonnets to Mother') (Miller, 1849: 41).

'The archetypal' combination in journals was to be, however, not diptychs but the collection of three three miniatures by Heine. 'Trilogies' were strung together independently from the author's intentions just as were the collections of pairs of miniatures. Yet they also allowed for a greater set of interlocking connections among their members - frequently adopting a typically Heineian triad of 'thesis-antithesis-synthesis'. Triptychs are characteristic of Heine's work: 'He devoted a great deal of attention to verse in collections, turning them into small chapters of fragmentary novels (where, possibly, they echo V.Schlegel's theoretical views on Petrarch's collections as fragmentary lyric novels).
Perhaps Heine might rather have collected them into 'trilogies' for the fact that the individual poems' tiny size can be taken as parodies set against Goethe's 'Trilogie der Leidenschaften' (Tynyanov, 1977: 32-33). In the above citation, Yu.N. Tynyanov implies, firstly, that the 'Neuer Frühling' cycle with its titles and internal numbering ('In der Fremde', 'Tragödie') may be compared with Goethe's large cycles, with their similar groupings, though they are not formally marked.

Heine's 'Triptychs' can be found among nearly every translator of the $19^{\text {th }}$ century, though this often took the form of imitation and parody on the translations of this poet. Let us name a few. N.P. Ogarev collected three poems of the cycle 'Die Heimkehr' (\#8, 14, 23) giving the miniatures the title: 'Rybachka', 'U morya', 'Ee portret' ('Du schönes Fischermädchen...', 'Das Meer erglänzte weit hinaus...', 'Ich stand in dunkeln Träumen...') (Ogarev, 1840: 1409-1410). The first two are, of course, combined by a common motif: the lyric hero sits on the seashore with a fisherman in the first case and, in the second, with his beloved. This is a classic example of coupling Heine's miniatures. It is tied to the original cycle with a single, passing motif. The second miniature sets the triptych's dramatic tone, being an antithesis with respect to the 'playfulness' of the first poems.

S tekh por sgorayu telom ya,

Dusha v toske iznyla -

Akh, eta zhenschina menya

Slezoyou otravila!

This stanza (the final one) sets up the third poem where, looking at the portrait of his beloved, the lyric hero is weeping.

In A. Fet's 'triptych', miniatures from two of Heine's cycles appear: 'Krasavitsa-rybachka..., 'Na severe dub odinokii..., 'Iz slez moikh mnogo 
roditsya...' ('Du schönes Fischermädchen...' from 'Die Heimkehr', \#8; 'Ein Fichtenbaum steht einsam...' and 'Aus meinen Tränen sprießen...' from 'Lyrisches Intermezzo', \#33, 2). With the 'dramatic' and explicit motives absent, the collection still does not 'fall apart' and it yet establishes a very 'Heineian' impression by the very virtue of its piecemeal composition. However, such fragmentation can be accounted as such only against the background of that in the original cycles. For a reader not acquainted with Heine in the original this piecemeal aesthetic would be incomprehensible.

In another form, L.A.Mei fashioned a triptych by including the following miniatures: 'Otravoi polny moi pesni...', 'Voet veter mezh derevyev...', 'Pogreben na perekrestke...' ('Vergiftet sind meine Lieder..., 'Der Herbstwind rüttelt die Bäume...', 'Am Kreuzweg wird begraben...') (Mei, 1858: 1185). The title indicates the cycle from which it was drawn: 'From Heine. (Intermezzo)', and the miniatures themselves have their numbers from the original cycle placed above them (LI, LVIII, LXII). (We shall note that Mei almost always indicates the original cycle and the number of the miniatures.) Thus the anthology does not change the order of the miniatures as fell in the original cycle, but the sense comes in the selection of them itself. Mei demonstrates the intentional character of the triptych's selection by the fact that in the previous numbers the verses 'Syna otechestva' were printed along with a poem from the same cycle ('Mne noch skovala ochi..., \#LXIV; 'V luchezarnoe letnee utro...', \#XLV). All translations, including that of the triptych, were inscribed ' 1 September 1858'. Thus nothing prevented Mei from rendering a more full segment of the original cycle, though he preferred to set together poems from more widely scattered portions of the original collection. These were diverse in their intonations, but together contributing to an overall dramatic effect. In this respect the final triptych deserves special mention. It was employed by different authors on several occasions namely to supply a 'dramatic end' for small journal collections, a practise that may be seen as a stable pattern.

On at least three occasions translations of Heine's miniatures appeared with the title 'Three Poems of Heine' in 'Russkii Vestnik' of 1857 (F. Miller) and in 'Otechestvennyi zapisy' of 1872 (A. Plesheev). We should note that both poets had published the first translations of their respective works from Heine in the 1840 s and thus included larger selections. Furthermore, they did not come out of collections in triadic groups.

Triptychs come in different types, but it is clearly not an accidental form of ordering. F. Miller put together miniatures from the smaller cycle 'Zum Lazarus' ('Ach, kak medlitel'no polzet...', 'Slubov'yu chernaya zhena..., 'Kak molnii vnezapnoi svet' - 'Wie langsam kriechet sie dachin..., 'Es hatte mein Haupt die schwarze Frau..., 'Ein Wetterstrahl beleuchtend plötzlich..., \#III, II, VIII). These had been written in the last years of the poet's life. The triptych is provided with a preface that is relatively large for a selection of three, page-long poems. Here the translator presents quotations from the afterword to 'Romancero' in which the poet speaks about his illness and gives his farewell to the reader. The translations are introduced by the following thought: 'This Heine wrote in 1851, and he went on to battle with death for another five years, never at any moment ceasing to jest till the end of his anguished life. Yet there were moments when this virile spirit withered in this hideous battle and dark despair for a time took hold of the poet's soul. This was the mood Heine expressed in a range of poems under the general title 'Lazarus' and 'Zum Lazarus'. In them can be heard the cries of suffering, mockery of the world and of life, fierce indignation, defiance and then resignation. We set forth before the 
reader three poems borrowed from these verses' (Miller, 1857: 206). The preface, therefore, serves to introduce the biographical and cyclical context of the miniatures which follow it and set the mood for the reader. In one way or another all the miniatures can be interpreted along the lines of illness and impending death. The triptych ends with the verses:

Umiloserdis', o tvorets!

I Ty nad uchestyu neschastnoi:

Poshli pokoi mne - i konets

Moei tragedii uzhastnoi!?

The only 'dynamic element' of the collection is in 'heightening the suffering'. Indeed, this is the sense on which the transition between the $2^{\text {nd }}$ and the $3^{\text {rd }}$ miniatures turns.

Plesheev's triptych includes the following miniatures from different cycles: 'Razgovor v dubrave', 'Schastya syny! Vasha zhizn' ne vnushyt...' ('Die Söhne des Glückes beneid ich nicht...'), 'Zhazhda otdykha' ('Ruhlechzend') (Plesheev, 1872: 293). All three poems have an ironic tinge. The first refers to Heine's early period and plays of the genre of 'dialogic' (question-answer) folk songs. In the second and third, written in the last years of the poet's life, he ironically confronts sickness, death, bewailing its proximity, and all this against the backdrop of mockery of 'the happy sons' and Catholicism (in one instance, 'good Christians', was replaced by Plesheev with 'pietists' in order to please the censors). The triptych is built upon contrast in subject, style and irony by Heine in different creative manners so that, over the course of three poems, Plesheev manages to fit in the whole of the poet's fate.

The title of two completely different triptychs ('Three poems by Heine'), formally indicates the number of poems in the collection. In fact it reflects the 'ideology' of the triptych, defining its semantic aura, and the regularity of this very quantitative feature of such poetic groupings.

No less common than these 'shamrocks' are collections of five poems found journals from the middle of the century. They often reproduce segments (of two or three poems together) taken from the original cycles. The peculiarity of these collections of five poems lies in the fact that five are together too many to be considered utterly random groupings and too few to reiterate the structural particularities of Heine's own cycles. On the other hand, one should note that these sets often represent small fragments of the original cycles that determine the principles linking the miniatures together. Most often translators in such collections start from narrative or genre principles in their compilations. One can find examples of a greatly differing quantities of poems brought together into collections. Rarely, quite large collections can be found, including fifteen to twenty, and more, verses in a single collection.

\section{Discussion}

The extent to which a translator reflects on the composition of the collections he chooses or the extent to which they may be randomly or spontaneously assorted is a matter that can only be addressed in each individual case. Analysis indicates that there is a particular correlation (though not always a necessary one) between the size of the anthology and the level of its structural coherence. In general, the larger the anthology the more 'accidental' its composition. While on the contrary, when a translator has in his arsenal only a few miniatures, he, in general, tries to impart a more clear logic to the whole of the composition. This is rather easy to explain. In larger collections the 'resistance of the material' from Heine's own cyclical choices is more keenly felt. In the smaller ones it is easier for the translator to tinker with 
the content according to his own scheme; he has more freedom to bring together the miniatures employing constructive principles that are closer to his taste. As a whole it is obvious that when working on translations, he reflects much less on how to compose the cycle. Heine remains the author of the translated works, which formally (but not functionally) absolves the translator from settling on the collection's compositional structure. This is emphasised when the common name of the collections includes the source 'From Heine' (for example: 'Motives from Heine', 'Poems. (From Heine)', 'Three Poems of Heine', and so forth.

It would be wrong to suggest that the author's reflections were invariably subordinated in the translated collections to the original cycles. They can often be seen as a quite original expression of a poetic cycle and, consequently, betray a more clear break with Heine's cyclical intentions. A rich base of material for analysing the development of such creative expression can be found in cases when a translator has published one collection and then, over time, widened selections in subsequent anthologies. Firstly, they may be taken as an uncollected cycle and, secondly, they often include a series of the same poems. Thus they demonstrate the various means in which the creator of the translated series conceives of how cycles are put together.

The basic problem of the Russian reception of Heine's cycles, and how that reception has been refracted in various cyclic anthologies, is that which lies at the heart of the 'inconstancy' fundamental to $19^{\text {th }}$ century Russian Heineialia. The German poet's lyric was always taken with an artificial isolation of its 'loving sentimentality' and 'ironic' elements. Heine's cycles present themselves as complex, advanced systems. Their structural elements have the capacity to alter their semantic functions over the course of being read. Poems that, at the beginning of the cycle, can be read as 'one dimensional' lyric miniatures, reveal themselves as jesting and ironic as the context of the cycle unfolds. This can be found in any of the cycles to some degree - their elements are interrelated and they work together to serve the author's intentions. Yet in the cases of Heine's cycles, this concerns not only the cooperating and mutually-compensating elements, but the inadequacy of each separate element to function in isolation from its context. Heine's irony, comprehensible only in the poet's own cycles and the realia of German literature, is closely related to, it would seem, the lyric miniatures alone and only clearly justified in this context. The lyrical and ironic contrasts so typical for Heine ring 'false' in translation. A.V.Federov noted in this regard that 'Heine's jokes and irony depend on the connections and relations between elements set together by the formation of the cycles in which they lie. Heine has many humorous separate poems (especially in the 'Lyrische Nachlese') that are small (four to six lines). While often the joke does not seem especially strong, thanks to its relation to the cycle as a whole it has a particular structural sense and it subsists like a "reflected symbol" of the cycle. In translations of separate poems excised from the cycle this relative irony disappears. We thus see the denuded vulnerability of an ill-placed joke. This vulnerability, as a fault, can even itself have a comic effect - and one quite unintended.' (Fedorov, 1929: 274).

Indeed the 'lyrical and sentimental' poetry taken out of context has a decidedly unHeineian ring to it. A stylistic eclecticism can even be observed in his early cycles. This is true less among individual poems, but rather in their sympathy/antipathy as they set themselves against a 'traditional' interpretation of their subject matter. In translations, thanks to both their violation of the original cycles and to the 'smoothing' approaches taken by many translations, mostly from the 1860 s, stylistic 
roughnesses were levelled over. Irony turned into self-irony against the translator himself, the play of traditional themes turned into poetic cliché. For Heine 'an apparently sentimental poem, or a tragic ballad can take on a particular hue by virtue of its proximity with things of a completely contradictory nature. The irony in the cycle is reflected in them and thus undermines the literary tradition in which they stand. Their translation results in a tear - not only in a journal but in all collections and selections of Heine's poetry, the verses serve only themselves, their link to the cycle is broken off. The 'Romancero' ballad (especially in Berg or V. Kostomarov's translations) turns into a traditional ballad, love poems, simply love poems' (Fedorov, 1935: 674). There were very few of Heine's cycles that shared these particularities in the $19^{\text {th }}$ century. For example, in an article unique for its time in posing the issue, A. von Vidert wrote that 'some of [Heine's] poems... when separate and not in connection with the others often say the opposite of what they would together, a peculiarity of Heine's' (Vidert, 1858: 76). In relation to the sub-cycle 'Verschiedene', starting from his own experience translating it, D.I. Pisarev noted: 'Our public not acquainted with the German language, has positively no knowledge of Heine. Nearly all of Heine's lyric poetry has been translated, but hardly anyone has translated it cycle by cycle. In the book 'Neue Gedichte' there are several lyric novels, each taking the name of a woman. 'Angelina', 'Katarina', 'Serafina', 'Emma', and others are made up of a number lyric poems in which various moments in the exchange of sentiments between man and woman are given shape. Our poets have translated individual poems from these cycles and they reflect Heine's physiognomy in their entirety...' (Pisarev, 1955: 345). Such remarks were atypical for Russian Heine specialists of the middle of the $19^{\text {th }}$ century. Discussion about the German poet invariably flowed into a line of reasoning concerning who the Russian Heine was and who he should be.

\section{Conclusion}

In general one may argue that translation anthologies must balance two motivations: the effort to present Heine (for example, one side of his lyric) and to present 'oneself in Heine', their 'interpretation' of his lyric. The latter intention applies particularly to the middle of the $19^{\text {th }}$ century in the context of debates surrounding the German poet. During this period, translators took great liberties with the original, changed it for ideological, moral and aesthetic reasons, excising and 'finishing' Heine's verse.

\footnotetext{
Seit jener Stunde verzehrt sich mein Leib, / Die Seele stirbt vor Sehen / Mich hat das unglücksel'ge Weib / Vergiftet mit ihren Tränen.

2 Erschüttert hat mich, was ich sah! / Auch du erbarm dich mein und spende / Die Ruhe mir, o Gott, und ende / Die schreckliche Tragödia (\#8).
}

\section{References}

Fedorov, A.V. (1929). The Russian Heine (40 th to $60^{\text {th }}$ years), In Russian poetry of the $19^{\text {th }}$ century. Leningrad, ACADEMIA, 248-298.

Fedorov, A.V. (1935). Heinrich Heine and the tsar's censorship, In Literaturnoye nasledstvo. Moscow, The Academy of Sciences of the USSR, 22-24, 635-678.

Mei, L. (1858). [translator] From Heine (Intermezzo), In Syn' otechestva. 41, 1185.

Miller, F. (1844). [translator] From Heine, In Moskvityanin. 21, 3.

Miller, F. (1848). [translator] From Heine, In Moskvityanin. 13, 14. 
Miller, F. (1849). Sonnets for mother (from Heine), In Moskvityanin. 13, 41.

Miller, F. (1857). The poems by Heine, In Russkii vestnik. September. Book 2, 206.

Ogarev, N. (1840). [translator] From Heine, In Literaturnaya gazeta. 63, 1409-1410.

Pisarev, D.I. (1955-1956). A collection of poems by foreign authors, In Pisarev D.I. Collected works in 4 vol. Moscow, Vol. 1.

Plesheev, A. (1872). The poems by Heine, In Otechestvennye zapiski. 3, March, 293-296.

Tynyanov, Yu.N. (1977). Poetics. History of Literature. Cinema. Moscow, 575 p.

Vidert, A. (1858). Heine's songs translated by M.L. Mikhailov, In Atenei. 29, 135-161.

\title{
Переводческие подборки из Гейне как лирические циклы
}

\author{
А.В.Ачкасов \\ Санкт-Петербургский государственный \\ университет \\ Россия, 199034, Санкт-Петербург, \\ Университетская наб., 7/9
}

Традиционно подборки переводов поэтических текстов не рассматриваются как единое композиционное целое. На материале переводов Г. Гейне на русский язык в статье показано, что такие подборки не являются случайныли, могут характеризоваться определенной законченностью и иметь собственную композицию. Проведенный анализ позволяет поставить вопрос о соотношении переводных цчиклов/подборок, с одной стороньл, с оригинальными цчиклами, а с другой - с особенностями авторской интенции переводчиков, которые определенным образом отбирают стихотворения для перевода и группируют стихотворения для публикации. Можно утверждать, что переводные подборки балансируют между двумя тенденииями: стремлением представить одну из сторон его лирики оригинального автора и стремлением создать новый лирический ичил, в определенной мере представляющий переводчика-соавтора. Ключевые слова: лирические ичикль Гейне, перевод, подборки переводов, рециклизациия.

Научная специальность: 10.02.00 - лингвистика, 24.00.00-культурология. 